\title{
The insights into the systematic relationship of Gastrostyla-affinitive genera, with report on a new saline soil ciliate genus and new species (Protozoa, Ciliophora)
}

Xiaoteng Lu ${ }^{1,2,3 \dagger}$, Yuanyuan Wang ${ }^{3 \dagger}$, Saleh A. Al-Farraj ${ }^{4}$, Hamed El-Serehy ${ }^{4}$, Jie Huang ${ }^{5}$ and Chen Shao ${ }^{1 *}$ (D)

\begin{abstract}
Background: Hypotrichia are a group with the most complex morphology and morphogenesis within the ciliated protists. The classification of Gastrostyla-like species, a taxonomically difficult group of hypotrichs with a common ventral cirral pattern but various dorsal and ontogenetic patterns, is poorly understood. Hence, systematic relationships within this group and with other taxa in the subclass Hypotrichia remain unresolved.

Results: $18 \mathrm{~S}$ rRNA gene sequence of a new Gastrostyla-like taxon was obtained. Phylogenetic analyses based on the $18 \mathrm{~S}$ rRNA gene sequences indicate that this ciliate represents a new genus that is closely related to Heterourosomoida and Kleinstyla within the oxytrichid clade of the Hypotrichia. However, the position of this cluster remains unresolved. All three genera deviate from the typical oxytrichids by their incomplete (or lack of) dorsal kinety fragmentation during morphogenesis. Morphology and morphogenesis of this newly discovered form, Heterogastrostyla salina nov. gen., nov. spec., are described. Heterogastrostyla nov. gen., is characterised as follows: more than 18 fronto-ventral-transverse cirri, cirral anlagen $\mathrm{V}$ and $\mathrm{VI}$ develop pretransverse cirri, and dorsal ciliature in Urosomoida-like pattern.
\end{abstract}

Conclusions: Similar to the CEUU-hypothesis about convergent evolution of urostylids and uroleptids, we speculate that the shared ventral cirral patterns of Gastrostyla-like taxa might have resulted from convergent evolution.

Keywords: Convergent evolution, Gastrostyla, morphogenesis, new genus, new species, saline soil habitat, $18 \mathrm{~S}$ rDNA phylogeny

\footnotetext{
* Correspondence: shaochen@snnu.edu.cn

${ }^{+}$Xiaoteng Lu and Yuanyuan Wang contributed equally to this work.

'Laboratory of Protozoological Biodiversity and Evolution in Wetland, College of Life Sciences, Shaanxi Normal University, Xi'an 710119, China

Full list of author information is available at the end of the article
}

(c) The Author(s). 2020 Open Access This article is licensed under a Creative Commons Attribution 4.0 International License, which permits use, sharing, adaptation, distribution and reproduction in any medium or format, as long as you give appropriate credit to the original author(s) and the source, provide a link to the Creative Commons licence, and indicate if changes were made. The images or other third party material in this article are included in the article's Creative Commons licence, unless indicated otherwise in a credit line to the material. If material is not included in the article's Creative Commons licence and your intended use is not permitted by statutory regulation or exceeds the permitted use, you will need to obtain permission directly from the copyright holder. To view a copy of this licence, visit http://creativecommons.org/licenses/by/4.0/ The Creative Commons Public Domain Dedication waiver (http://creativecommons.org/publicdomain/zero/1.0/) applies to the data made available in this article, unless otherwise stated in a credit line to the data. 


\section{Background}

Hypotrichia are a group with the most complex morphology and morphogenesis within the ciliated protists. They are thus increasingly recognized as being of significance to the study of cell biology, genetics and ecology [1-15].

Among hypotrichs, Gastrostyla-like species are a group of superficially similar taxa that have at least seven frontoventral cirri (derived from anlagen IV-VI) in a more or less continuous slightly oblique row [16-19]. Gastrostylalike forms include species belonging to the genera Neogastrostyla Kaur et al., 2019 [20], Gastrostyla Engelmann, 1862 [21], Kleinstyla Foissner et al., 2002 [22], Apogastrostyla Li et al., 2010 [17], Hemigastrostyla Song and Wilbert 1997 [19], Protogastrostyla Gong et al., 2007 [23], and Pseudogastrostyla Fan et al., 2015 [24].

Despite sharing a common ventral cirral pattern, the systematic position of Gastrostyla-like species is still problematic [16, 25-28]. Generally, there are two possibilities: (i) Gastrostyla-like species were ancestors of the typical 18 FTV-cirri oxytrichids, that is, the 18 FTVcirral pattern evolved from a Gastrostyla-like pattern by a reduction of the cirri originating from anlagen IV-VI [29, 30]; or (ii) Gastrostyla-like species evolved from 18 FTV-cirri oxytrichids independently by increasing the number of cirri originating from anlagen IV-VI [16].

In April 2015, an undescribed Gastrostyla-like species was isolated from saline soil within the Longfeng Wetland Nature Reserve, a district of Daqing, northern China. Analyses of its morphology and cell division, as well as the small subunit ribosomal DNA (SSU rDNA) sequence, indicate that it represents a new species and a new genus. Phylogenetic analyses of all available Gastrostyla-like species were performed.

\section{Results}

\section{SSU rDNA sequence and phylogenetic analyses (Fig. 1)}

The SSU rDNA sequence of Heterogastrostyla salina nov. spec. was deposited in the GenBank database with the accession number MT739409. The length and GC content of the SSU rDNA sequence are $1687 \mathrm{bp}$ and $46.00 \%$, respectively. Phylogenetic trees inferred from the SSU rDNA sequences using two different methods, i.e., maximum likelihood (ML) and Bayesian inference (BI), show similar topologies, therefore we present only the ML tree with bootstraps and posterior probabilities from both algorithms (Fig. 1).

Heterogastrostyla salina clusters with Heterourosomoida lanceolata and Kleinstyla dorsicirrata with high support (ML/BI, 98/1.00), differing from them in 8 and 19 nucleotide sites, respectively. Other Gastrostyla-like species, distantly related to $H$. salina, fall into several groups: (i) Hemigastrostyla, Apogastrostyla and Protogastrostyla occupy the basal positions within the hypotrich assemblage although with low nodal support; (ii)
Pseudogastrostyla flava clusters with Rubrioxytricha ferruginea with low support (ML/BI, 72/0.94); (iii) Gastrostyla steinii nests within the typical oxytrichids; (iv) Neogastrostyla aqua falls within a fully supported clade of Oxytricha granulifera populations (ML/BI, 100/1.00).

\section{Cladistics relationship and morphological patterns of Gastrostyla-like species (Figs. 2 and 3)}

A cladogram of Gastrostyla-like species was constructed based on the presence/absence of dorsomarginal/dorsal fragmentation, the fate of the old dorsal kineties, the number of caudal cirri and whether anlage $\mathrm{V}$ contributes to pretransverse ventral cirri (Fig. 2). We also provide illustrations showing the morphology of Gastrostyla-like genera for clarity (Fig. 3). Heterogastrostyla salina, Kleinstyla dorsicirrata, Pseudogastrostyla flava, and Neogastrostyla aqua form one clade, because they have dorsomarginal rows. Other Gastrostyla spp. are separated from this clade due to their incomplete, or the complete absence of, dorsal kinety fragmentation. Neogastrostyla aqua is distinguished from $H$. salina, K. dorsicirrata and $P$. flava by its anlage $\mathrm{V}$ not contributing to pretransverse ventral cirri. Pseudogastrostyla flava is distinguished from $H$. salina and $K$. dorsicirrata by the number of caudal cirri. In $H$. salina, the dorsal fragmentation is absent, whereas $K$. dorsicirrata has incomplete fragmentation. As concerns Gastrostyla-like taxa without dorsomarginal rows, Hemigastrostyla differs from Apogastrostyla rigescens and Protogastrostyla pulchra in exhibiting multiple dorsal kinety fragmentation, whereas A. rigescens and $P$. pulchra are distinguished from each other by the retention/resorption of the parental dorsal kineties.

Heterogastrostyla nov. gen.

Order Sporadotrichida Fauré-Fremiet, 1961

\section{Diagnosis}

Body flexible. Undulating membranes slightly curved. More than 18 fronto-ventral-transverse cirri grouped in Oxytricha-like pattern. Cirral anlagen V and VI develop pretransverse cirri. One right and one left marginal row. Dorsal ciliature in Urosomoida-like pattern: three main dorsal kineties and one dorsomarginal row. Caudal cirri present.

\section{Type species \\ Heterogastrostyla salina nov. spec.}

\section{Etymology}

Composite of the Greek adjective heteros (different) and the well-known genus name Gastrostyla. This indicates that Heterogastrostyla has a similar ventral ciliature to 


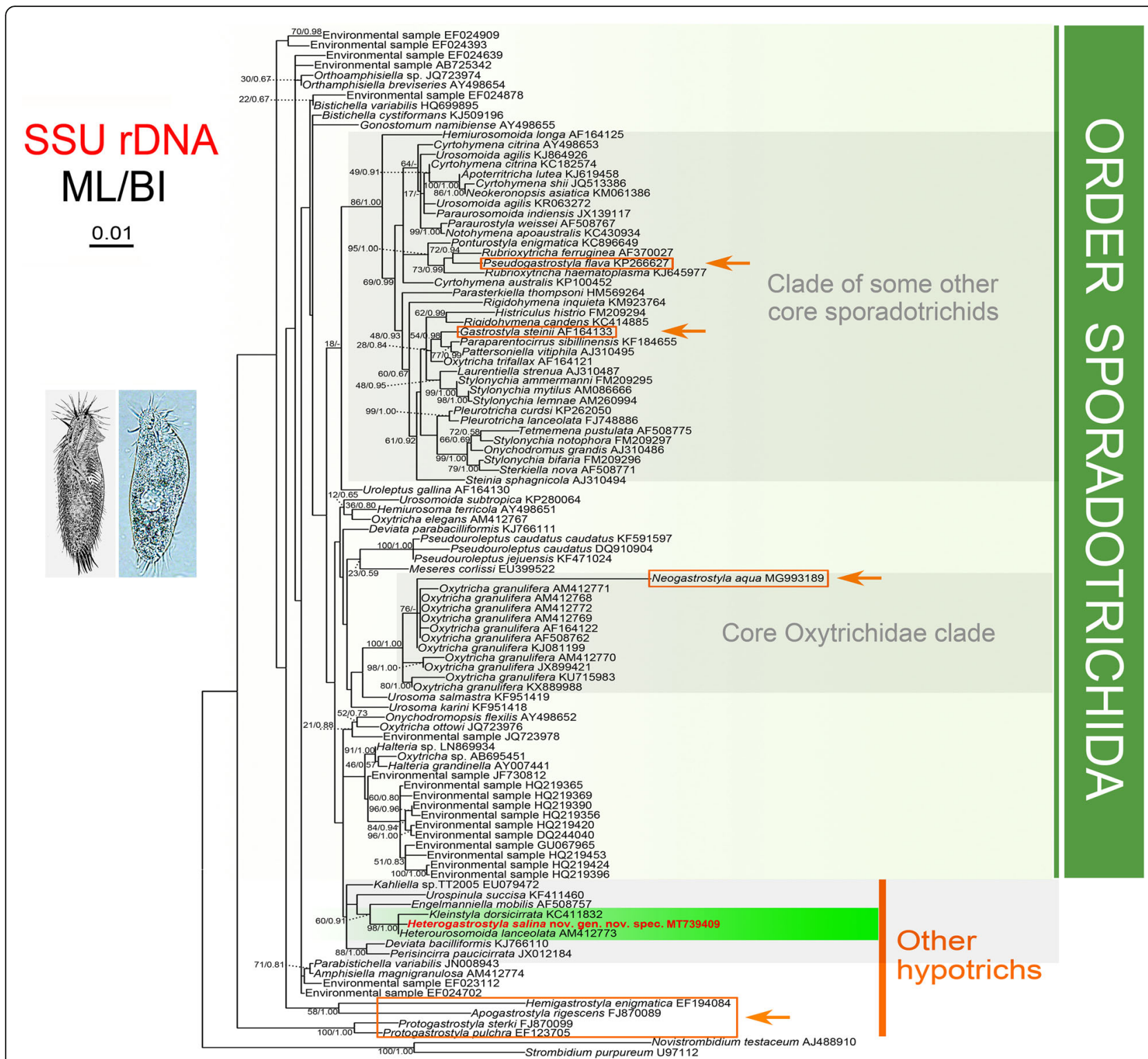

Fig. 1 Maximum likelihood (ML) tree inferred from SSU rDNA sequences showing the systematic position of Heterogastrostyla salina nov. spec. (bold) and other Gastrostyla-like species (frames with arrows). Numbers near nodes are nonparametric bootstrap values for ML and posterior probability values for Bayesian inference (BI). "-" refers to disagreement in topology with the BI tree. All branches are drawn to scale. We have omitted most names of higher taxa because, as in most (all?) other trees, the taxa are non-monophyletic. The scale bar corresponds to 0.01 expected substitutions per site.

Gastrostyla but differs in the dorsal side. Feminine gender.

\section{Heterogastrostyla salina nov. spec. Diagnosis}

Size in vivo $100-120 \times 30-45 \mu \mathrm{m}$, outline in ventral view elliptical. Two macronuclear nodules, two micronuclei. Contractile vacuole slightly ahead of mid-body. Adoral zone composed of 25-31 membranelles. 2124 fronto-ventral-transverse cirri, some frontoventral and postoral ventral cirri form a more or less continuous row. Left and right marginal row composed of 27-37 and 21-31 cirri, respectively. Three bipolar dorsal kineties with one short dorsomarginal kinety in Urosomoida-like pattern. Three caudal cirri. Saline soil habitat.

\section{Type locality}

Saline soil from the Longfeng Wetland Nature Reserve, Daqing, northern China (Fig. $4 \mathrm{~d}-\mathrm{f}$; lat. $46^{\circ} 35^{\prime} 30^{\prime \prime} \mathrm{N}$, long. $125^{\circ} 13^{\prime} 08^{\prime \prime} \mathrm{E}$; for details, see Material and Methods). 


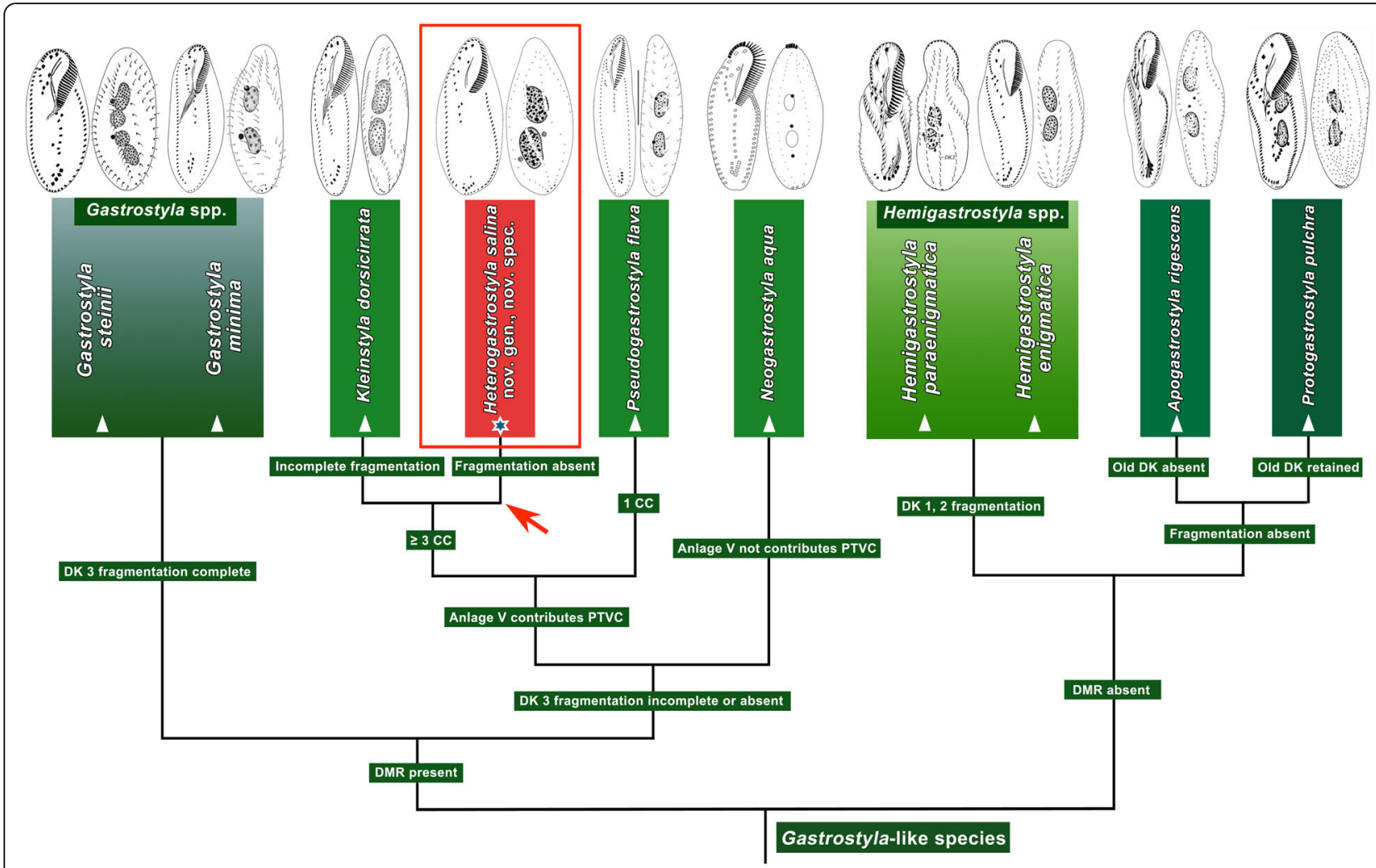

Fig. 2 Cladogram of Gastrostyla-like species based upon pattern of dorsal kineties, arrow and the red frame mark the Heterogastrostyla salina nov. spec. clade. CC, caudal cirri; DK, dorsal kinety; DMR, dorsomarginal row; PTVC, pretransverse ventral cirri.

\section{Etymology}

The species-group name salina refers to the saline habitat where the type specimen was discovered.

\section{Type slides}

The protargol-stained slide with the holotype specimen (Figs. $4 \mathrm{~b}, \mathrm{c}$ and $5 \mathrm{~g}$ ) circled in ink is deposited in the Natural History of Museum, London, UK (registration number NHMUK2020.4.4.1). One protargol slide with paratype specimens are deposited in the Laboratory of Protozoology, Ocean University of China (OUC, registration number: Leo2015041601).

\section{ZooBank registration}

Registration number of the present work: lsid:zoobank.org:pub:B0946886-C083-421B-8BD3-35D261200B79

Morphology of Heterogastrostyla salina nov. spec. (Figs. 4 a-c and 5 a-k, Table 1)

Body size $100-120 \times 30-45 \mu \mathrm{m}$ in vivo $(n=12)$, usually $120 \times 40 \mu \mathrm{m}$; in protargol preparations $110 \times 45 \mu \mathrm{m}$ on average. Specimens widened during protargol preparation procedures (Table 1); length to width ratio about 3: 1 in vivo (Figs. 4 a and $5 \mathrm{a}-\mathrm{d}$ ). Cell outline long elliptical or lanceolate, rounded at both ends with anterior portion sometimes slightly narrowed (Figs. $4 \mathrm{~b}$ and $5 \mathrm{~b}$ ); cell flexible and slightly contractile. Body dorsoventrally flattened about 1.5:1, dorsal side slightly convex, ventral side slightly concave (Fig. 5 c). Nuclear apparatus located along, or slightly left of, cell midline, composed of two ellipsoidal macronuclear nodules and one to six, on average two, micronuclei attached, or near to the macronuclear nodules; macronuclear nodules about $25 \times 15$ $\mu \mathrm{m}$ in size (in protargol preparations), micronuclei about $4 \mu \mathrm{m}$ across (Fig. $4 \mathrm{c}$; Table 1). Cortical granules not observed. In protargol-impregnated specimens, extruded spindle-shaped extrusomes, $2-3 \times 1-1.5 \mu \mathrm{m}$, were observed in marginal region of cortex (Fig. $5 \mathrm{f}$ ). Cytoplasm colourless to greyish, containing numerous lipid droplets (ca. 2-3 $\mu \mathrm{m}$ across) and refractive crystals $(1-6 \mu \mathrm{m}$ across) that render cell opaque and dark at low magnification (Fig. $5 \mathrm{c}-\mathrm{e}$ ). One contractile vacuole about $12 \mu \mathrm{m}$ across, positioned slightly ahead of mid-body, near left margin (Figs. 4 a and 5 a). Locomotion mainly by slow to fast crawling on substrate; in cultures, cells usually aggregate around rice grains or bottom detritus.

Adoral zone about $40 \mu \mathrm{m}$ long, composed of 25-31 membranelles, occupying ca. $30 \%$ of body length in vivo, and about $35 \%$ in protargol preparations; cilia of distal membranelles $15-20 \mu \mathrm{m}$ long; cilia of proximal 

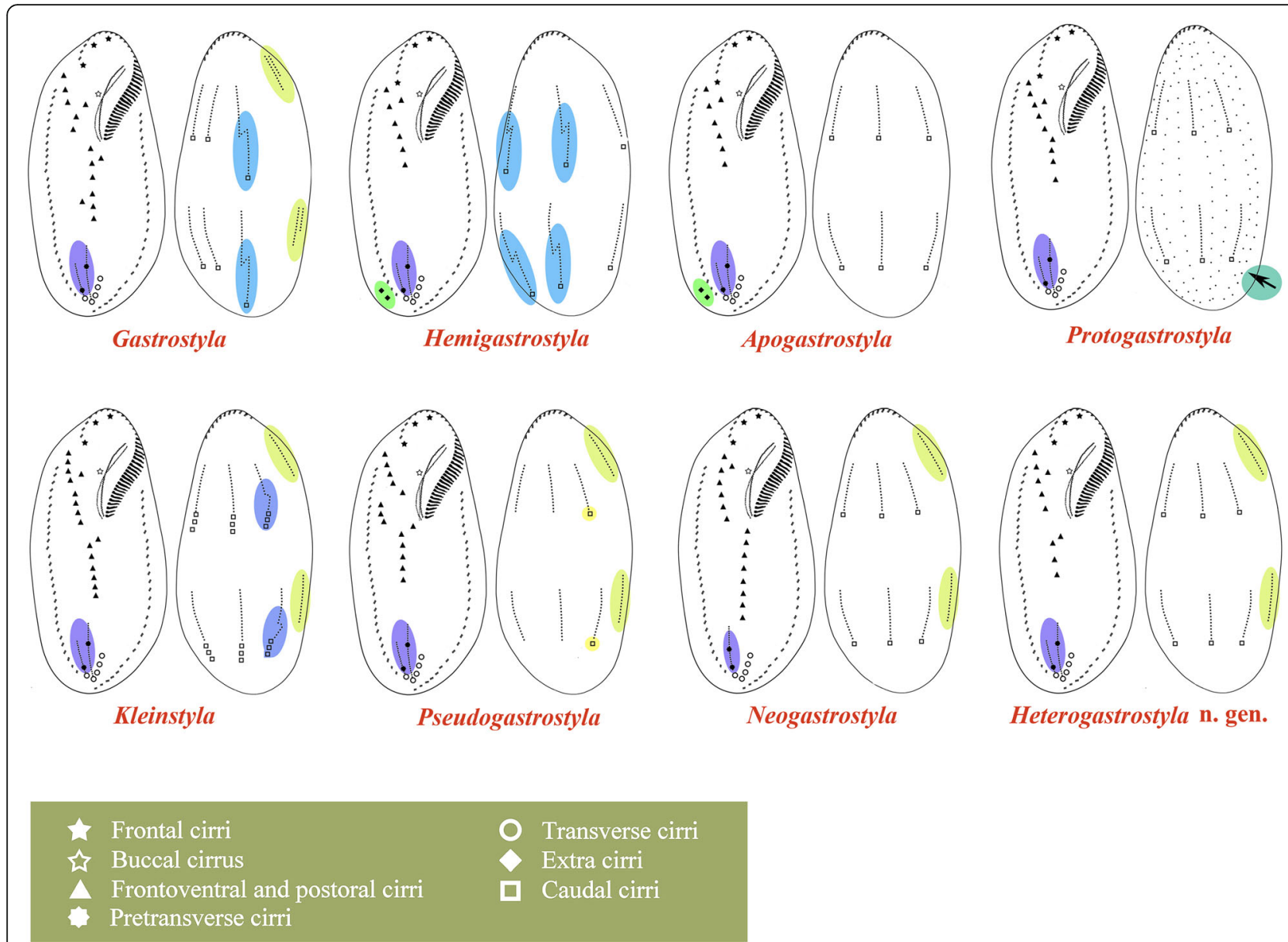

Fig. 3 Diagram of the infraciliature, and formation patterns of pretransverse ventral cirri (with dotted lines connecting cirri that develop from the same cirral streaks) and dorsal ciliature of eight genera. Arrow marks the parental kineties which are retained in the daughter cells. Purple, blue and yellow shaded area represent the pretransverse cirri, dorsal kinety pattern and dorsomarginal kineties, respectively.

membranelles 10-15 $\mu \mathrm{m}$ long. Undulating membranes almost straight and in Oxytricha-like pattern, paroral and endoral almost equal in length, about $25 \mu \mathrm{m}$ long. Three enlarged frontal cirri, cilia of which are ca. $20 \mu \mathrm{m}$ long. One buccal cirrus, ca. $15 \mu \mathrm{m}$ long, located adjacent to anterior end of paroral. Six (rarely seven or eight) frontoventral cirri (Figs. $4 \mathrm{~b}$ and $5 \mathrm{~h}$, i), cilia of which are 12-15 $\mu \mathrm{m}$ long. Four (rarely five) postoral ventral cirri (Figs. $4 \mathrm{~b}$ and $5 \mathrm{j}, \mathrm{k}$ ), cilia of which are $12-15 \mu \mathrm{m}$ long. All frontoventral and postoral ventral cirri (except of cirri III/2 and IV/2) form a more or less continuous row (Figs. $4 \mathrm{~b}$ and $5 \mathrm{~h}-\mathrm{k}$ ). Left and right marginal row composed of 27-37 and 21-31 cirri, respectively, cilia of which are 12-15 $\mu \mathrm{m}$ long; left row J-shaped, terminates at posterior end of cell, behind the rearmost transverse cirrus; right row commences at about level of second frontoventral cirrus and terminates at about level of lower pretransverse cirrus. Two pretransverse cirri. Five enlarged transverse cirri in J-shaped pattern (Fig. 4 b). Dorsal kineties in typical Urosomoida-like pattern, i.e. three dorsal kineties, each bearing a caudal cirrus at posterior end, and one dorsomarginal row terminating at about mid-body; dorsal kinety 1 (leftmost) usually slightly to distinctly shortened anteriorly (Fig. 4 c).

\section{Ontogenesis of Heterogastrostyla salina nov. spec. (Figs. 5} I-s, 6 a-j and $7 \mathrm{a}, \mathrm{b})$

The earliest stage observed had six long primary frontoventral-transverse (FVT) anlagen with a differentiating oral primordium in the opisthe (Fig. 6 a).

\section{Stomatogenesis}

In the opisthe, the formation of membranelles commences left of the anterior end of the oral primordium (Fig. 6 a). As the formation of adoral membranelles proceeds posteriad, the undulating membranes anlage (= FVT-anlage I) contributes the leftmost frontal cirrus and splits longitudinally into two streaks from which the endoral and paroral are formed (Figs. $5 \mathrm{l}$ and $6 \mathrm{e}, \mathrm{g}$, i). 


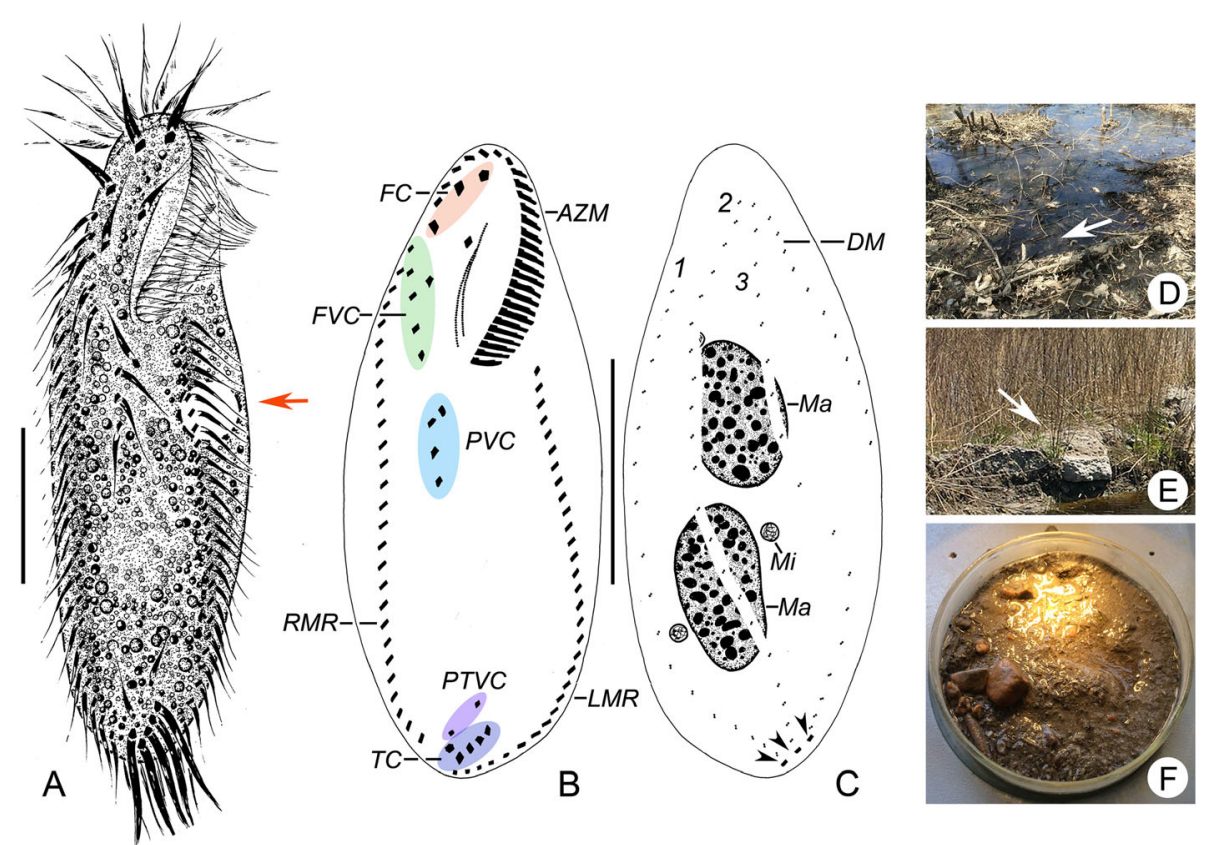

Fig. 4 a-c Morphology and infraciliature and of Heterogastrostyla salina nov. spec. from life (a) and after protargol staining (b, c). a Ventral view of a typical individual, arrow marks the contractile vacuole. b, c Ventral (b) and dorsal (c) view of the same individual, arrowheads in (c) depict the caudal cirri. $\mathbf{d}$, e Surroundings of the sampling sites, arrows indicate where the soil samples were collected. $\mathbf{f}$ Photograph showing the raw culture in a non-flooded Petri dish. AZM, adoral zone of membranelles; DM, dorsomarginal kinety; FC, frontal cirri; FVC, frontoventral cirri; LMR, left marginal row; Ma, macronuclear nodules; Mi, micronuclei; PVC, postoral ventral cirri; PTVC, pretransverse ventral cirri; RMR, right marginal row; TC, transverse cirri. 1-3, dorsal kineties 1-3. Scale bars $=30 \mu \mathrm{m}(\mathbf{a}) ; 40 \mu \mathrm{m}(\mathbf{b}, \mathbf{c})$.

In the proter, the parental undulating membranes gradually dedifferentiate into an undulating-membrane anlage. The differentiation of the undulating membranes anlage follows a similar pattern to that in the opisthe (Fig. 6 c, e, g, i). Interestingly, on one middle stage specimen, we found a small patch of densely distributed kinetids posterior to frontoventral anlage $\mathrm{I}$ in the proter (Figs. $5 \mathrm{n}$ and $6 \mathrm{~d}$ ), but this small patch disappeared in the next stage (Fig. 6 g). We deduce that it is a remnant of the FVT-anlagen. The parental adoral zone of membranelles is retained intact during the morphogenetic process (Figs. 6 a, e, g, i and 7 a).

\section{Development of frontoventral ciliature}

The FVT-anlagen II-VI develop as primary primordia and then divide into two groups transversely, one for each daughter cell (Figs. 5 l-n and 6 a, e, g). Subsequently, anlagen I-VI of each group segregate new cirri in the normal pattern: 1:3:3:4:5:5 (Figs. 5 o q and 6 i). After migration and differentiation, three frontal, one buccal, six to eight frontoventral, four or five postoral ventral, two pretransverse and five transverse cirri are formed. The origination of ventral ciliature is as follows: (i) the leftmost front frontal cirrus comes from anlage I; (ii) the middle frontal cirrus and buccal cirrus come from anlage II; (iii) the rightmost frontal cirrus originates from anlage III; (iv) the six frontoventral cirri come from anlage III $(\times 1)$, anlage IV $(\times 2)$ and anlage $\mathrm{V}(\times 3)$; (v) the four postoral ventral cirri come from anlage IV $(\times 1)$ and anlage $\mathrm{V}(\times 3)$; the two pretransverse cirri come from anlage $\mathrm{V}(\times 1)$ and anlage $\mathrm{VI}$ $(\times 1)$; and the five transverse cirri derive from the posterior end of anlagen II-IV, respectively (Figs. $6 \mathrm{i}$ and $7 \mathrm{a}$ ).

\section{Marginal rows}

In each divider, the marginal rows anlagen develop intrakinetally. These anlagen then increase in size by adding basal bodies on the right side of the parental structure (Fig. 6 e). Meanwhile, the parental rows are gradually resorbed (Fig. 6 g, i).

\section{Dorsal kineties}

In the earliest stage, several patches of the dorsal-kinety (DK) anlagen appeared intrakinetally in the middle of each old structure without a clear separation for the proter and the opisthe (Fig. 6 b); Whether the DK-anlagen are primary primordia is not clear, however, since their early development is not known. Dorsal morphogenesis proceeds in Urosomoida-like pattern, i.e. the new dorsal kineties develop intrakinetally as three anlagen each in the proter and opisthe without fragmentation, and each dorsal kinety produces one caudal cirrus in the late stage (Figs. 5 s, 6 b, f, h, j and 7 b). It is noteworthy that a 


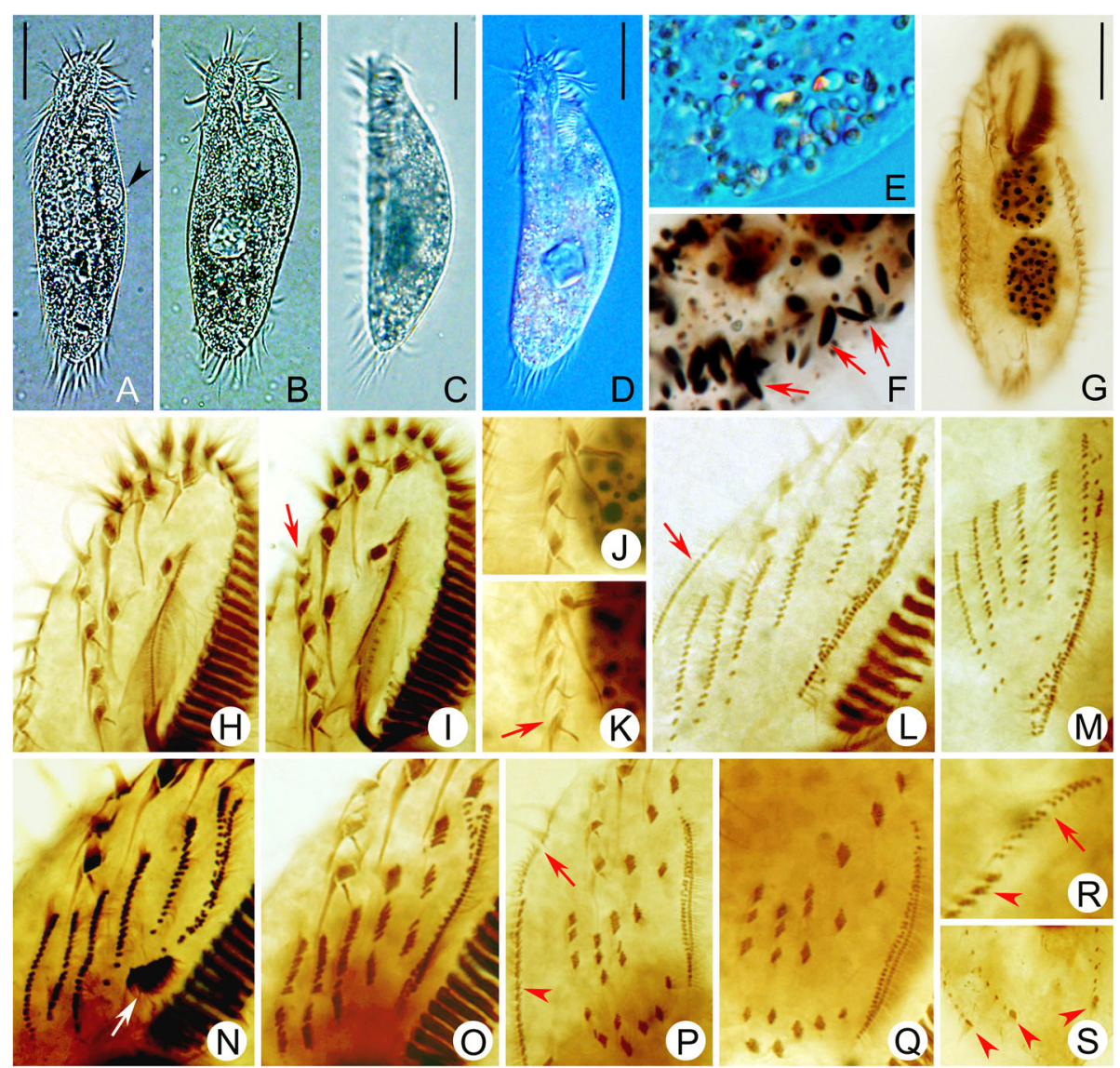

Fig. $\mathbf{5}$ a-s Photomicrographs of Heterogastrostyla salina nov. spec. from life (a-e) and after protargol staining (f-s). a-d Different body shapes, arrowhead in (a) indicates the contractile vacuole. e Cytoplasm containing numerous lipid droplets and refractive crystals. $\mathbf{f}$ Showing the spindleshaped extrusomes (arrows) after protargol staining. $\mathbf{g}$ Ventral view of the holotype specimen. $\mathbf{h}, \mathbf{i}$ Ventral view to show the frontoventral ciliature, arrow depicts the additional frontoventral cirri. $\mathbf{j}, \mathbf{k}$ Ventral view to show the postoral ventral ciliature, arrow indicates the additional postoral ventral cirri. I, $\mathbf{n}-\mathbf{p}, \mathbf{r}$ Development ventral development in the proter, arrow in (I) and arrowhead in (r) indicate the anlage for the right marginal row; arrow in $(\mathbf{n})$ depicts the small patch of densely distributed kinetids posterior to the frontoventral anlage l; arrows in (p) and (r) denote the dorsomarginal anlage (dikinetidal row) that originates from the anterior of the right marginal anlage. $\mathbf{m}$, $\mathbf{q}$ Development frontoventral-transverse anlagen in the opisthe. $\mathbf{s}$ Dorsal view of a late divider, arrowheads show the caudal cirri. Scale bars $=30 \mu \mathrm{m}(\mathbf{a}-\mathbf{e})$.

short dikinetid-row appears anterior of the right marginal anlagen, more or less distinctly separated from the right marginal anlagen (Figs. 5 p, r and 6 i). This is the dorsomarginal kinety anlage. It is unclear whether the dorsomarginal kinety anlage derives from the anterior portion of the right marginal anlage and later moves to the dorsal side.

\section{Division of nuclear apparatus}

The nuclear apparatus divides in the usual way, i.e., the two macronuclear nodules fuse to form a single mass during the mid-divisional stage which then divide twice prior to cytokinesis (Figs. 6 b, f, h, j and 7 b).

\section{Physiological reorganization}

Only one early stage of physiological reorganization was observed (Fig. 7 c, d), which indicated that the early process of cortical development in reorganizers is similar to morphogenesis.

\section{Discussion}

Phylogenetic position of the new genus Heterogastrostyla and related taxa

The present phylogenetic analyses show that Heterogastrostyla nov. gen. is most closely related to Heterourosomoida and Kleinstyla. However, the systematic position of this group is far from being resolved, as indicated by the variable statistical support in the SSU rDNA tree (Fig. 1).

The grouping of Heterogastrostyla, Heterourosomoida, and Kleinstyla was supported by their morphological similarities in that all these three genera exhibit deviation from the typical oxytrichid fragmentation of dorsal kinety 3 . The former two genera share the same Urosomoida-like pattern in which fragmentation of dorsal 
Table 1 Morphometric characterisation of Heterogastrostyla salina nov. spec

\begin{tabular}{|c|c|c|c|c|c|c|c|}
\hline Character $^{\mathbf{a}}$ & Min & Max & Mean & M & SD & CV & $n$ \\
\hline Body length & 95 & 130 & 111.5 & 115 & 9.2 & 8 & 25 \\
\hline Body width & 35 & 55 & 44.8 & 45 & 4.5 & 10 & 25 \\
\hline Body length: width ratio & 2.1 & 3.0 & 2.5 & 2.5 & 0.3 & 10.1 & 25 \\
\hline Paroral, length & 20 & 25 & 23.6 & 25 & 2.3 & 9.2 & 25 \\
\hline Endoral, length & 20 & 25 & 23.8 & 25 & 2.2 & 8.7 & 25 \\
\hline Adoral zone of membranelles, length & 30 & 45 & 38.3 & 40 & 3.9 & 9.9 & 25 \\
\hline Adoral zone of membranelles, length: body length ratio & 0.26 & 0.47 & 0.34 & 0.35 & 0.04 & 11.6 & 25 \\
\hline Adoral membranes, number & 25 & 31 & 27.8 & 28 & 1.8 & 6.3 & 25 \\
\hline Frontal cirri, number & 3 & 3 & 3.0 & 3 & 0.0 & 0.0 & 25 \\
\hline Buccal cirri, number & 1 & 1 & 1.0 & 1 & 1.0 & 1.0 & 25 \\
\hline Frontoventral cirri, number & 6 & 8 & 6.3 & 6 & 0.6 & 9.3 & 25 \\
\hline Postoral ventral cirri, number & 4 & 5 & 4.0 & 4 & 0.2 & 5.0 & 25 \\
\hline Pretransverse ventral cirri, number & 2 & 2 & 2.0 & 2 & 0.0 & 0.0 & 25 \\
\hline Transverse cirri, number & 4 & 5 & 4.9 & 5 & 0.3 & 5.5 & 25 \\
\hline Right marginal cirri, number & 21 & 31 & 27.0 & 27 & 2.3 & 8.7 & 25 \\
\hline Left marginal cirri, number & 27 & 37 & 32.6 & 33 & 2.1 & 6.3 & 25 \\
\hline Dorsal kineties, number & 3 & 3 & 3.0 & 3 & 0.0 & 0.0 & 25 \\
\hline Dorsomarginal row, number & 1 & 1 & 1.0 & 1 & 1.0 & 1.0 & 25 \\
\hline Caudal cirri, number & 3 & 3 & 3.0 & 3 & 0.0 & 0.0 & 25 \\
\hline Macronuclear nodules, number & 2 & 2 & 2.0 & 2 & 0.0 & 0.0 & 25 \\
\hline Micronuclei, number & 1 & 6 & 2.0 & 2 & 1.1 & 56.6 & 25 \\
\hline Anterior macronuclear nodule, length & 20 & 30 & 23.4 & 24 & 3.0 & 12.6 & 25 \\
\hline Anterior macronuclear nodule, width & 10 & 16 & 14.9 & 15 & 1.5 & 10.2 & 25 \\
\hline Micronuclei, length & 3 & 5 & 4.1 & 4 & 0.9 & 21.7 & 25 \\
\hline Micronuclei, width & 3 & 5 & 4.1 & 4 & 0.9 & 21.7 & 25 \\
\hline
\end{tabular}

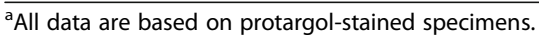

CV coefficient of variation in \%, M median, Max maximum, Mean arithmetic mean, Min minimum, $n$ number of cells measured, SD standard deviation. The length measurement are in microns.

kinety 3 is lost, whereas Kleinstyla exhibits incomplete fragmentation of dorsal kinety 3 [18]. Neogastrostyla aqua, resembles $H$. salina in terms of the dorsal ciliary pattern, however, they are not closely related in the SSU rDNA tree as $N$. aqua nests robustly within the Oxytricha granulifera clade. Similarly, Gastrostyla is distinctively placed within the oxytrichid clade, which is consistent with assertion of Wirnsberger et al. (1986) that G. steinii is a stylonychine oxytrichid [31]. Other Gastrostyla-like genera, i.e., Pseudogastrostyla, Apogastrostyla, Protogastrostyla, and Hemigastrostyla, are consistently placed outside the oxytrichid clade, as shown in the previous studies $[17,23]$.

The cladogram based on the dorsal ciliary pattern (Fig. 2) of Gastrostyla-like species is broadly consistent with the molecular tree (Fig. 1). With the presence of the dorsomarginal row, Heterogastrostyla salina shows a close relationship with Kleinstyla dorsicirrata and Pseudogastrostyla flava. Together with Gastrostyla spp., they are closely related to oxytrichids, whereas ApogastrostylaProtogastrostyla-Hemigastrostyla are distinctly separated from the oxytrichid clade since they lack a dorsomarginal row. The presence/absence of dorsomarginal kineties plays a significant role in the classification of hypotrichs, supporting the Dorsomarginalia hypothesis [32].

\section{Establishment of the new genus}

In possessing more than 18 fronto-ventral-transverse cirri that form a continuous, slightly oblique row, Heterogastrostyla nov. gen. is similar to the following genera: Neogastrostyla Kaur et al., 2019 [20], Gastrostyla Engelmann, 1862 [21], Kleinstyla Foissner et al., 2002 [22], Pseudogastrostyla Fan et al., 2015 [24], Hemigastrostyla Song and Wilbert, 1997 [19], Apogastrostyla Li et al., 2010 [17] and Protogastrostyla Gong et al., 2007 [23]. The most distinct feature that separates Heterogastrostyla from related genera is its Urosomoida-like dorsal ciliature pattern, i.e., fragmentation of dorsal kinety 

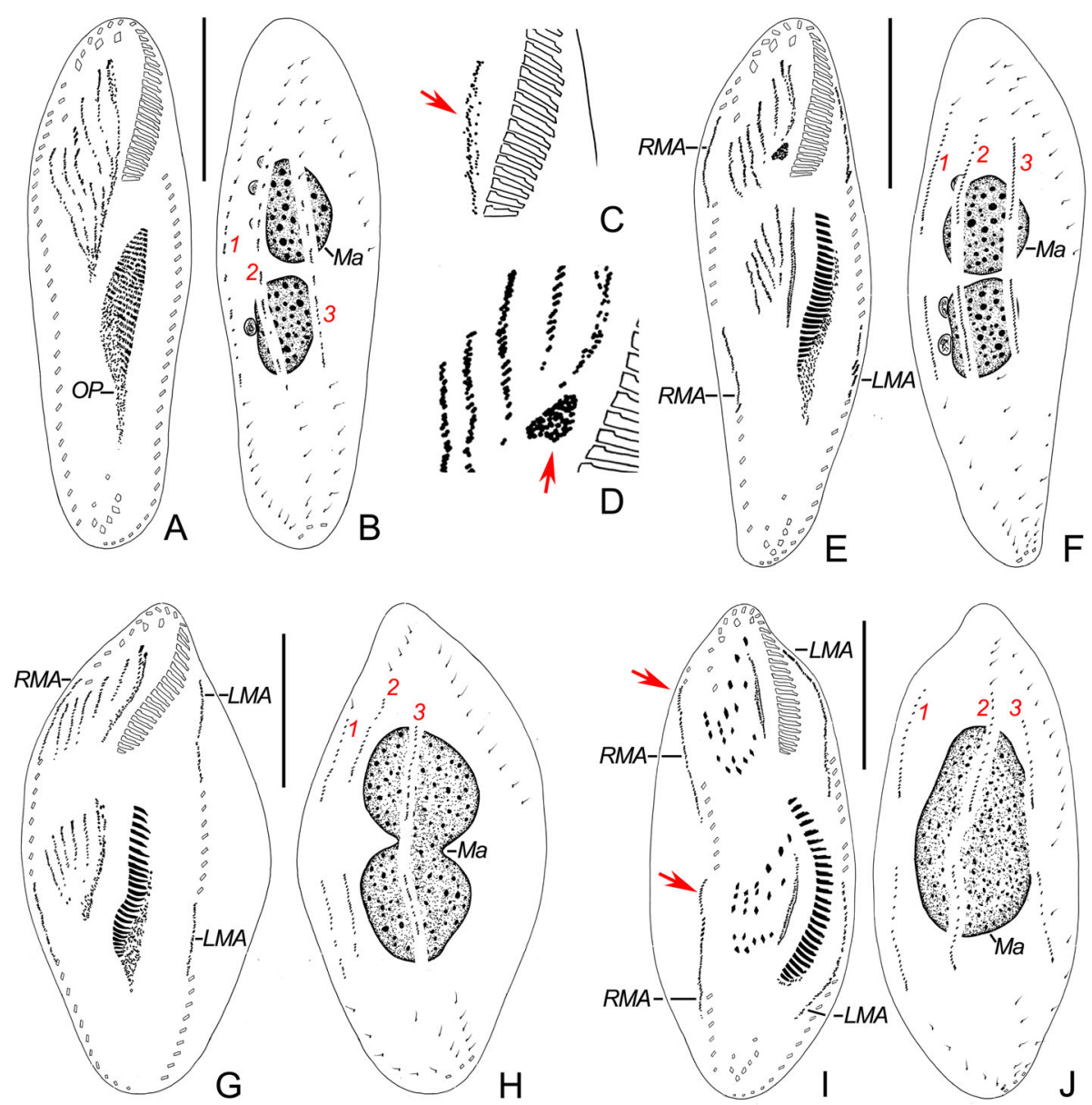

Fig. 6 a-j Early and middle stages of morphogenesis in Heterogastrostyla salina nov. spec. after protargol staining. a, e, g, i Ventral views to show the development of oral primordium, fronto-ventral-transverse anlagen and marginal rows anlagen, arrows in (i) indicate dorsomarginal anlagen (dikinetidal row) that originate from the anterior of right marginal anlage. c Showing the resorption of parental undulating membranes (arrow) in the proter as depicted in (a). d Magnified view of the fronto-ventral-transverse anlagen as shown in (e), arrow indicates the small patch of densely distributed kinetids posterior to the frontoventral anlage I in the proter. $\mathbf{b}, \mathbf{f}, \mathbf{h}, \mathbf{j}$ Dorsal views to show the development of dorsal kineties and nuclear apparatus. LMA, anlage for the left marginal row; Ma, macronuclear nodules; OP, oral primordium; RMA, anlage for the right marginal row; $1-3$, dorsal kineties anlagen $1-3$. Scale bars $=40 \mu \mathrm{m} \mathbf{a}-\mathbf{j}$.

anlage 3 is lost during ontogenesis. Based on this, Neogastrostyla closely resembles Heterogastrostyla. However, the former can be distinguished from the latter by cirral anlage $\mathrm{V}$ not contributing a pretransverse ventral cirrus, i.e. both pretransverse cirri develop from anlage VI (vs. cirral anlagen $\mathrm{V}$ and $\mathrm{VI}$ each generates a pretransverse ventral cirrus in Heterogastrostyla). Due to these morphogenetic differences, a new genus is established.

\section{Morphological comparison of Heterogastrostyla salina nov. spec. with related Gastrostyla-like taxa}

Heterogastrostyla salina belongs to the group of Gastrostyla-like taxa which share a similar ventral cirral pattern: (i) frontoventral cirri derived from anlagen IV-VI form a more or less continuous, slightly oblique row, and (ii) fronto-ventral-transverse cirri either retain the typical pattern of 18 FVT-cirri or number more than 18 FVT-cirri.
We therefore compare our new form with eight typical Gastrostyla-like species, namely, Neogastrostyla aqua Kaur et al., 2019, Gastrostyla steinii Engelmann, 1862, G. minima Hemberger, 1985, Kleinstyla dorsicirrata (Foissner, 1982) Foissner et al., 2002, Pseudogastrostyla flava Fan et al., 2015, Hemigastrostyla paraenigmatica Shao et al., 2011, H. enigmatica (Dragesco and DragescoKernéis, 1986) Song and Wilbert, 1997, Apogastrostyla rigescens (Kahl, 1932) Li et al., 2010, and Protogastrostyla pulchra (Perejaslawyewa, 1886) Gong et al., 2007.

Neogastrostyla aqua can be easily distinguished from Heterogastrostyla salina by the number of dorsomarginal kineties (two vs. one), frontoventral cirri (that is, cirri in the anterior portion of frontoventral row in Kaur et al. 2019) (5 or 6 vs. 6-8) and postoral ventral cirri (that is, postoral ventral cirri and cirri in the posterior portion of frontoventral row in Kaur et al. 2019) (8 or 9 vs. 4 or 5) [20]. 


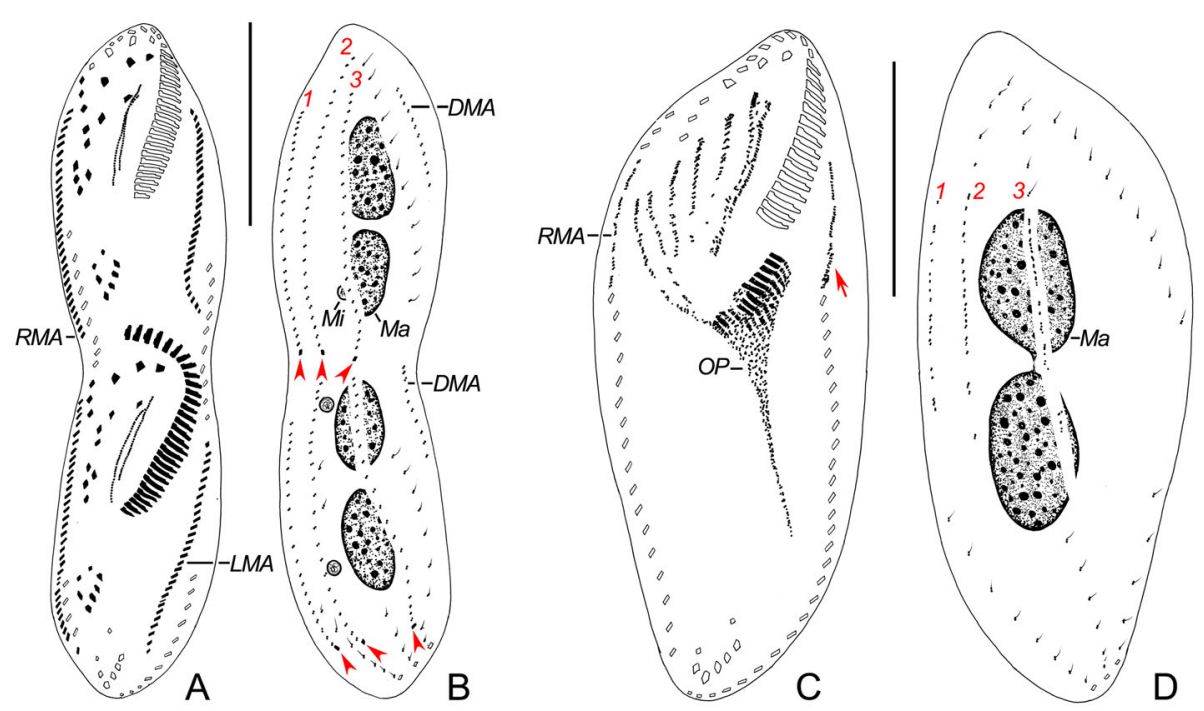

Fig. 7 a-d Late stage of morphogenesis $(\mathbf{a}, \mathbf{b})$ and middle stage of reorganization $(\mathbf{c}, \mathbf{d})$ in Heterogastrostyla salina nov. spec. after protargol staining. a, $\mathbf{c}$ Ventral views to show the development of the oral primordium, fronto-ventral-transverse anlagen and marginal rows anlagen, arrow in (c) depicts the anlage for the left marginal row. $\mathbf{b}$, $\mathbf{d}$ Dorsal views to show the development of dorsal kineties and nuclear apparatus, arrowheads in (b) indicate the newly differentiated caudal cirri. DMA, dorsomarginal anlage; Ma, macronuclear nodules; Mi, micronuclei; OP, oral primordium; RMA, anlage for the right marginal row; 1-3, dorsal kineties anlagen 1-3. Scale bars $=50 \mu \mathrm{m}(\mathbf{a}, \mathbf{b}) ; 40 \mu \mathrm{m}(\mathbf{c}, \mathbf{d})$.

Gastrostyla steinii, the type species of the genus Gastrostyla, can be easily distinguished from Heterogastrostyla salina by: (i) the number of macronuclear nodules (four vs. two); (ii) a higher and variable number of fronto-ventral-transverse cirri (27-32 vs. 21); (iii) the segregation pattern of fronto-ventral-transverse cirri from anlagen I-VI (1:2:3:3:11-13:7-10 vs. 1:3:3:4:5:5); and (iv) the dorsal kinety pattern (Oxytricha-like pattern vs. Urosomoida-like pattern) [16, 33].

Gastrostyla minima differs from Heterogastrostyla salina as follows: (i) cortical granules present (vs. absent); (ii) dorsal kineties in an Oxytricha-like (vs. Urosomoidalike) pattern; (iii) some cirri greatly reduced in size and/ or slightly out of line (vs. cirri of uniform size and aligned regularly), and; (iv) the total number of frontoventral-transverse cirri (22-31 vs. 21) [16, 34, 35].

Heterogastrostyla salina can be distinguished from Kleinstyla dorsicirrata by: (i) the number of caudal cirri (three, one each at the posterior end of kineties 1-3 vs. nine on average, with $3-6,2-4,1-3$ at the end of kineties 1-3, respectively); (ii) dorsal kineties in a Urosomoida-like (vs. Oxytricha-like) pattern; (iii) the segregation pattern of fronto-ventral-transverse cirri from anlagen I-VI (1:3:3:4:5:5 vs. 1:3:3:4-7:6-10:6-9), and; (iv) the total number of fronto-ventral-transverse cirri (21 vs. 28) [16, 33, 35].

Pseudogastrostyla flava can be easily distinguished from Heterogastrostyla salina by: (i) the number of caudal cirri (one vs. three); (ii) cortical granules (present vs. absent), and; (iii) biotope (brackish water vs. terrestrial) [24].
Heterogastrostyla salina can be distinguished from Hemigastrostyla paraenigmatica by: (i) the shape of the anterior portion of the cell (not cephalized vs. cephalized); (ii) the extra cirri (absent vs. present); (iii) cortical granules (absent vs. present); (iv) the length of the distal portion of the adoral zone (not extending far posteriorly vs. extending far posteriorly); (v) the number of adoral membranelles (28 vs 42 ); (vi) dorsal kineties in a Urosomoida-like (vs. Hemigastrostyla-like) pattern; (vii) the number of dorsal kineties (three vs. five), and; (viii) the total number of fronto-ventral-transverse cirri (21 vs. 18) $[16,19,36,37]$.

Heterogastrostyla salina differs from Hemigastrostyla enigmatica by: (i) dorsal kineties in a Urosomoida-like (vs. Hemigastrostyla-like) pattern; (ii) the number of dorsal kineties (three vs. five); (iii) the extra cirri (absent vs. present); (iv) the body size $(110 \times 45 \mu \mathrm{m}$ vs. $142 \times 63$ $\mu \mathrm{m}$ in protargol preparation); (v) the length of the distal portion of adoral zone (not extending far posteriorly vs. extending far posteriorly); (vi) the number of adoral membranelles (28 vs 50); (vii) the length of the adoral zone $(38 \mu \mathrm{m}$ vs. $57 \mu \mathrm{m})$, and; (viii) the total number of fronto-ventral-transverse cirri (21 vs. 18) [38].

Heterogastrostyla salina can be separated from Apogastrostyla rigescens by: (i) the shape of the anterior portion of the cell (not cephalized vs. cephalized); (ii) the pattern of undulating membranes (Oxytricha-like vs. Stylonychia-like); (iii) the length of the distal portion of adoral zone (not extending far posteriorly vs. extending far posteriorly); (iv) the extra cirri (absent vs. present); (v) dorsal kineties in a Urosomoida-like (vs. Gonostomum- 
like) pattern; (vi) cortical granules (absent vs. present); (vii) ring-shaped structures (absent vs. present); (viii) the body size $(110 \times 45 \mu \mathrm{m}$ vs. $150 \times 42 \mu \mathrm{m}$ in protargol preparation); (ix) the number of adoral membranelles (28 vs 43); (vi) the length of the adoral zone ( $38 \mu \mathrm{m}$ vs. $61 \mu \mathrm{m}$ ); (vii) the total number of fronto-ventraltransverse cirri (21 vs. 18), and; (viii) biotope (terrestrial vs. marine) $[17,29]$.

Protogastrostyla pulchra differs from Heterogastrostyla salina by: (i) the fate of the parental dorsal kineties (retained vs. resorbed); (ii) the number of dorsal kineties (9-11 vs. three); (iii) the number of adoral membranelles (54 vs 28); (iv) the length of the distal portion of adoral zone (extending far posteriorly vs. not extending far posteriorly); ( $\mathrm{v}$ ) the position of the transverse cirri (distinctly displaced anteriad vs. close to rear body margin); (vi) cortical granules (present vs. absent); (vii) the body size $(153 \times 72 \mu \mathrm{m}$ vs. $110 \times 45 \mu \mathrm{m}$, in protargol preparations); (viii) the course of the right and left marginal rows (overlapping at rear end of cell vs. not overlapping), and; (ix) biotope (marine vs. terrestrial) [16, 23, 39-41].

Heterogastrostyla salina resembles Urosomoida, Paraurosomoida, Hemiurosomoida, and Heterourosomoida in terms of its dorsal ciliature, i.e., fragmentation of dorsal kinety 3 is lost. However, H. salina can be distinguished from these taxa by its Gastrostyla-like ventral cirral pattern.

\section{Morphogenesis of Heterogastrostyla salina nov. spec.}

Morphogenetic characteristics of the new species basically correspond with that of Neogastrostyla aqua Kaur et al., 2019, except for development of the pretransverse ventral cirri [20]. In the latter, all cirri (except for a single transverse cirrus) generated from cirral anlage $\mathrm{V}$, move anteriad to form the postoral ventral cirri, that is, cirral anlage $\mathrm{V}$ does not develop any pretransverse cirri. However, in $H$. salina, some cirri generated from cirral anlage $\mathrm{V}$ move anteriad to form postoral ventral cirri, while others move posteriad to form a pretransverse and a transverse cirrus.

Although morphogenesis of the new species closely resembles that of Gastrostyla spp., it differs in that: (1) fronto-ventral-transverse cirral anlagen are formed from primary primordia (vs. in secondary primordia), and; (2) the dorsal kineties anlagen are in a Urosomoida-like (vs. an Oxytricha-like) pattern [4, 33, 42]

A comparison of ontogenesis of Gastrostyla-like species is summarized in Table 2 . The ventral development of Heterogastrostyla salina proceeds basically as in Hemigastrostyla, Apogastrostyla, and Protogastrostyla. Specifically, six primary FVT-anlagen generate an increased number $(>18)$ of fronto-ventral-transverse cirri, with frontoventral cirri not regularly grouped but arranged in a more or less continuous, slightly oblique (frontoventral) row. Heterogastrostyla salina, however, differs significantly from the above mentioned three genera in: (i) the fate of the parental adoral membranelles in the proter (completely retained vs. only apical part of old adoral zone retained, combining the newly built membranelles formed from the proter's oral primordium), and; (ii) the dorsal development (Urosomoida-like pattern vs. Gonostomum-like pattern or Hemigastrostylalike pattern). It should be noted that in Protogastrostyla, the dorsal kinety anlagen are unique since the primary primordia and old dorsal kineties are retained, resulting in a higher number (9-11) of dorsal kineties [28].

\section{Conclusions}

Similar to the CEUU-hypothesis in urostylids and uroleptids (Foissner et al., 2004), we speculate that the shared ventral cirral patterns of Gastrostyla-like species might result from the convergent evolution from four major groups: (i) true oxytrichids with both a dorsomarginal row and complete fragmentation of dorsal kinety 3 (e.g., Gastrostyla steinii); (ii) those with a dorsomarginal row but without, or with incomplete, dorsal fragmentation (e.g., Heterogastrostyla nov. gen., Kleinstyla, and Pseudogastrostyla); (iii) those without a dorsomarginal row but with multiple fragmentation of dorsal kineties 1 and 2 (e.g., Hemigastrostyla); and (iv) those in which both the dorsomarginal row and dorsal kinety fragmentation are absent (e.g., Protogastrostyla and Apogastrostyla). We assume that the "Gastrostyla-like ventral cirral pattern" evolved at least twice independently in the above-mentioned groups. Since the ventral ciliature is linked with motility, foraging and food uptake, the evolutionary pressure on the ventral ciliature is much stronger than on the dorsal ciliature, which is possibly sensoric and therefore is more conservative [25]. This might explain why the Gastrostyla-like species are scattered throughout the SSU rDNA tree and not in a single group. This supports the CEUU-hypothesis in that it is insufficient to determine the systematic positions of hypotrichs solely by their ventral cirral pattern [43]. Future studies should combine dorsal patterns with molecular analyses to obtain a more robust phylogeny.

\section{Methods}

Saline soil samples $(0-10 \mathrm{~cm}$; salinity of soil percolate about 20\%; pH 10.0) were collected in the Longfeng Wetland Nature Reserve (lat. $46^{\circ} 35^{\prime} 30^{\prime \prime} \mathrm{N}$, long. $125^{\circ} 13^{\prime}$ 08"E), Daqing, northern China, on 16 April 2015. Samples were malodorous (very likely due to hydrogen sulphide), and included a large proportion of rotten leaves and branches. For preservation and future isolation, samples were dried at room temperature (about 24 ${ }^{\circ} \mathrm{C}$ ) immediately after collection. 
Table 2 Morphogenesis comparisons of Gastrostyla-like species

\begin{tabular}{|c|c|c|c|c|c|c|c|}
\hline Character $^{a}$ & $\begin{array}{l}\text { Heterogastrostyla } \\
\text { salina nov. gen., } \\
\text { nov. spec. }\end{array}$ & $\begin{array}{l}\text { Neogastrostyla } \\
\text { aqua }\end{array}$ & $\begin{array}{l}\text { Gastrostyla } \\
\text { spp. }\end{array}$ & $\begin{array}{l}\text { Hemigastrostyla } \\
\text { paraenigmatica }\end{array}$ & $\begin{array}{l}\text { Hemigastrostyla } \\
\text { enigmatica }\end{array}$ & $\begin{array}{l}\text { Apogastrostyla } \\
\text { rigescens }\end{array}$ & $\begin{array}{l}\text { Protogastrostyla } \\
\text { pulchra }\end{array}$ \\
\hline Parental AZM & $\begin{array}{l}\text { Completely } \\
\text { retained }\end{array}$ & $\begin{array}{l}\text { Completely } \\
\text { retained }\end{array}$ & $\begin{array}{l}\text { Completely } \\
\text { retained }\end{array}$ & $\begin{array}{l}\text { Only apical } \\
\text { part retained }\end{array}$ & $\begin{array}{l}\text { Only apical } \\
\text { part retained }\end{array}$ & $\begin{array}{l}\text { Only apical } \\
\text { part retained }\end{array}$ & $\begin{array}{l}\text { Only apical part } \\
\text { retained }\end{array}$ \\
\hline FVTA & $\begin{array}{l}\text { Primary } \\
\text { primordia }\end{array}$ & Primary primordia? & $\begin{array}{l}\text { Secondary } \\
\text { primordia }\end{array}$ & $\begin{array}{l}\text { Primary } \\
\text { primordia }\end{array}$ & $\begin{array}{l}\text { Primary } \\
\text { primordia }\end{array}$ & $\begin{array}{l}\text { Primary } \\
\text { primordia }\end{array}$ & Primary primordia \\
\hline $\begin{array}{l}\text { Anlage V } \\
\text { contribute PTVC }\end{array}$ & Yes & No & Yes & Yes & Yes & Yes & Yes \\
\hline RMA & Intrakinetally & Intrakinetally & Intrakinetally & De novo & De novo & De novo & De novo \\
\hline LMA & Intrakinetally & Intrakinetally & Intrakinetally & Intrakinetally & De novo & Intrakinetally & $\begin{array}{l}\text { Intrakinetally in } \\
\text { proter and/or de } \\
\text { novo in opisthe (?) }\end{array}$ \\
\hline $\begin{array}{l}\text { RMA anterior } \\
\text { part differentiated } \\
\text { into paired basal } \\
\text { bodies, which } \\
\text { then become } \\
\text { dorsomarginal row }\end{array}$ & Yes & No & No & Yes & No & No & Yes \\
\hline $\begin{array}{l}\text { Formation of } \\
\text { extra cirri }\end{array}$ & No & No & No & Yes & Yes & Yes & No \\
\hline DKA & $\begin{array}{l}\text { Likely primary } \\
\text { primordia }\end{array}$ & $\begin{array}{l}\text { Secondary } \\
\text { primordia }\end{array}$ & $\begin{array}{l}\text { Secondary } \\
\text { primordia }\end{array}$ & $\begin{array}{l}\text { Likely primary } \\
\text { primordia }\end{array}$ & $\begin{array}{l}\text { Secondary } \\
\text { primordia }\end{array}$ & $\begin{array}{l}\text { Likely primary } \\
\text { primordia }\end{array}$ & Primary primordia \\
\hline Dorsal pattern & $\begin{array}{l}\text { Urosomoida- } \\
\text { like pattern }\end{array}$ & $\begin{array}{l}\text { Urosomoida- } \\
\text { like pattern }\end{array}$ & $\begin{array}{l}\text { Oxytricha-like } \\
\text { pattern }\end{array}$ & $\begin{array}{l}\text { Hemigastrostyla- } \\
\text { like pattern }\end{array}$ & $\begin{array}{l}\text { Hemigastrostyla- } \\
\text { like pattern }\end{array}$ & $\begin{array}{l}\text { Gonostomum- } \\
\text { like pattern }\end{array}$ & $\begin{array}{l}\text { Gonostomum-like } \\
\text { pattern }\end{array}$ \\
\hline Parental DK & $\begin{array}{l}\text { Completely } \\
\text { resorbed }\end{array}$ & Completely resorbed & $\begin{array}{l}\text { Completely } \\
\text { resorbed }\end{array}$ & $\begin{array}{l}\text { Completely } \\
\text { resorbed }\end{array}$ & $\begin{array}{l}\text { Completely } \\
\text { resorbed }\end{array}$ & $\begin{array}{l}\text { Completely } \\
\text { resorbed }\end{array}$ & Retained \\
\hline Data source & present work & $\begin{array}{l}\text { Kaur et al. } \\
\text { (2019) [20] }\end{array}$ & $\begin{array}{l}\text { Foissner } \\
\text { (1982) [33] }\end{array}$ & $\begin{array}{l}\text { Song and Wilbert } \\
\text { (1997) [19] }\end{array}$ & $\begin{array}{l}\text { Shao et al. } \\
\text { (2013) [38] }\end{array}$ & $\begin{array}{l}\text { Li et al. } \\
\text { (2010) [17] }\end{array}$ & $\begin{array}{l}\text { Hu and Song } \\
(2000)[39]\end{array}$ \\
\hline
\end{tabular}

${ }^{\mathrm{a}}$ Data are based on protargol-stained specimens. Measurements in $\mu \mathrm{m}$.

Abbreviations: AZM adoral zone of membranelles, DK dorsal kineties, DKA dorsal kinety anlagen, FVTA fronto-ventral-transverse anlagen, LMA left marginal anlage, $P T V C$ pretransverse ventral cirri, $R M A$ right marginal anlage.

Ciliates were stimulated to excyst by applying the nonflooded Petri dish method [22]. They were then isolated and non-clonal cultures were established at room temperature (about $23{ }^{\circ} \mathrm{C}$ ) in Petri dishes containing filtered soil percolate and squeezed rice grains to enrich the bacterial food.

Living specimens were observed using bright field and differential interference contrast microscopy [31]. Protargol preparation was used to reveal the ciliature and the nuclear apparatus [44]. Counts and measurements of prepared specimens were performed at a magnification of $1,000 \times$. Drawings of protargol-prepared cells were made with the aid of a drawing device (camera lucida). To illustrate the changes occurring during morphogenesis, old (parental) structures were depicted by contour whereas new ones were shaded black. Terminology and systematics basically follow Lynn (2008) [45]; for terms specific for hypotrichs, see references $[16,25,26,32]$

\section{DNA extraction, PCR amplification and sequencing}

Genomic DNA was extracted from single cells using DNeasy Tissue kit (Qiagen, CA) following the manufacturer's instructions, with the modification that $25 \%$ of the volume suggested for each reagent solution was used. The SSU rRNA gene was amplified according to [46] and [9], using the primers 18S-F (5'-AAC CTG GTT GAT CCT GCC AGT-3') and 18S-R (5'-TGA TCC TTC TGC AGG TTC ACC TAC-3') [47].

\section{Phylogenetic analyses}

A set of 104 SSU rDNA sequences was used in the present study, including the newly obtained sequence of Heterogastrostyla salina nov. spec., sequences of 82 related hypotrichs, 19 closely related environmental sequences and two oligotrichs, namely, Novistrombidium testaceum and Strombidium purpureum as the outgroup taxa (see Fig. 1 for accession numbers). Sequences were aligned in GUIDANCE and ambiguous columns in the alignment were removed with the set parameters (below 0.956), using the GUIDANCE web server [48, 49]. Further modifications were made manually, using BioEdit 7.0 [50]. Ambiguously aligned regions and gaps were excluded prior to the phylogenetic analyses resulting in a matrix of 1,692 characters. Maximum likelihood (ML) 
analysis was performed, using RAxML-HPC2 v8.2.12, on XSEDE [51] on the online server CIPRES Science Gateway [52] with the GTR + G + I model as the optimal choice. Support for the best ML tree came from 1,000 bootstrap replicates with the GTR + CAT model. Bayesian inference (BI) analysis was performed with MrBayes v3.2.6 on XSEDE [53] on the online server CIPRES Science Gateway, using the GTR + I + G model as selected by MrModeltest v.2.0 [54]. Markov chain Monte Carlo (MCMC) simulations were run with two sets of four chains for 2,000,000 generations with a sampling frequency of 100 and a burn-in of 5,000 trees (25\%). All remaining trees were used to calculate posterior probabilities using a $50 \%$ majority rule consensus. TreeView v1.6.6 [55] and MEGA 4.0 [56] were used to visualize the tree topologies. For interpretation of bootstrap values we follow Vd'ačný and Rajter (2015); that is, we consider values $\geq 95$ as high, from $70-94$ as moderate, from $50-70$ as low, and $<50$ as representing no support [57]. Bayesian posterior probability values $<0.95$ are considered as low and values $\geq 0.95$ as high [58].

\section{Abbreviations}

18S rRNA: Small subunit ribosomal RNA; BI: Bayesian inference; bp: Base pairs; DK: Dorsal kinety; FVT: Fronto-ventral-transverse cirri; GC: Guanine-cytosine; GTR + I + G: General time reversible + invariable sites + gamma model of nucleotide substitution; ML: Maximum likelihood; nov. spec.: Nova species; PCR: Polymerase chain reaction; spp.: Species (plural)

\section{Acknowledgements}

The authors would like to express their gratitude to Professor Weibo Song (OUC) for his constructive suggestions. The authors would also like to thank anonymous reviewers for their thoughtful critiques that helped improve the manuscript. In addition, the authors would like to express their sincere thanks to Dr. Alan Warren, for his helpful critiques in enhancing language within this manuscript.

\section{Authors' contributions}

$\mathrm{XL}$ collected the samples, carried out the live observation, protargol preparations and morphometrics and drafted the manuscript; YW was responsible for DNA amplification and sequencing, and drafted the manuscript; JH and YW carried out the molecular phylogenetic analyses. SAA and HES were responsible for the language correction. CS did the identification of the species, taxonomic analysis and revision of the manuscript. All authors prepared the manuscript and approved the final version.

\section{Funding}

This work was financially supported by the Natural Science Foundation of China (Project numbers: 31872190; 31801984), the Marine S\&T Fund of Shandong Province for Pilot National Laboratory for Marine Science and Technology (Qingdao) (No. 2018SDKJ0406-1) and research project of King Saud University (RSP-2020/7). Xiaoteng Lu is supported by the Chinese Scholarship Council. The funding bodies had no role in the design or implementation of this study or in preparation of the manuscript.

\section{Availability of data and materials}

Sequence data are available in GenBank (Accession Number: MT739409). The datasets used and/or analyzed during the current study are available from the corresponding author on reasonable request. One permanent slide containing the protargol-impregnated holotype specimen of Heterogastrostyla salina nov. gen., nov. spec. circled by ink is deposited in the Natural History Museum, London (registration number NHMUK2020.4.4.1). One paratype slide is deposited in the Laboratory of Protozoology, Ocean University of China (OUC, registration number: Leo2015041601).
Ethics approval and consent to participate

Not applicable.

\section{Consent for publication}

Not applicable.

\section{Competing interests}

The authors declare that they have no competing interests.

\section{Author details}

${ }^{1}$ Laboratory of Protozoological Biodiversity and Evolution in Wetland, College of Life Sciences, Shaanxi Normal University, Xi'an 710119, China. ${ }^{2}$ Research Department for Limnology, Mondsee, University of Innsbruck,

Mondseestrasse 9, A-5310 Mondsee, Austria. ${ }^{3}$ Institute of Evolution \& Marine Biodiversity, Ocean University of China, Qingdao 266003, China. ${ }^{4}$ Zoology Department, King Saud University, Riyadh 11451, Saudi Arabia. ${ }^{5}$ Key Laboratory of Aquatic Biodiversity and Conservation of Chinese Academy of Sciences, Institute of Hydrobiology, Chinese Academy of Sciences, Wuhan 430072, China.

Received: 5 September 2019 Accepted: 17 July 2020

Published online: 29 July 2020

\section{References}

1. Jung $\mathrm{JH}$, Berger $\mathrm{H}$. Monographic treatment of Paraholosticha muscicola (Ciliophora, Keronopsidae), including morphological and molecular biological characterization of a brackish water population from Korea. Eur J Protistol. 2019;68:48-67.

2. Zhang T, Dong J, Cheng T, Duan L, Shao C: Reconsideration of the taxonomy of the marine ciliate Neobakuella aenigmatica Moon et al., 2019 (Protozoa, Ciliophora, Hypotrichia). Mar Life Sci Technol. 2020;2:97-108.

3. Lu X, Huang J, Shao C, Berger H. Morphology, cell-division, and phylogeny of Schmidingerothrix elongata spec. nov. (Ciliophora, Hypotricha), and brief guide to hypotrichs with Gonostomum-like oral apparatus. Eur J Protistol. 2018:62:24-42

4. Luo X, Yan Y, Shao C, Al-Farraj SA, Bourland WA, Song W. Morphological, ontogenetic and molecular data support strongylidiids as being closely related to Dorsomarginalia (Protozoa, Ciliophora) and reactivation of the family Strongylidiidae Fauré-Fremiet, 1961. Zool J Linnean Soc. 2018;184: 237-54

5. Lyu Z, Wang J, Huang J, Warren A, Shao C. Multigene-based phylogeny of Urostylida (Ciliophora, Hypotrichia), with establishment of a novel family. Zool Scr. 2018;47:243-54.

6. Wang J, Zhao Y, Lu X, Lyu Z, Warren A, Shao C: Does the Gonostomumpatterned oral apparatus in hypotrichia carry a phylogenetic signal? Evidence from morphological and molecular data based on extended taxon sampling using three nuclear genes (Ciliophora, Spirotrichea). Sci China Life Sci. 2020:1-12

7. Shao C, Hu C, Fan Y, Warren A, Lin X. Morphology, morphogenesis and molecular phylogeny of a freshwater ciliate, Monomicrocaryon euglenivorum euglenivorum (Ciliophora, Oxytrichidae). Eur J Protistol. 2019;68:25-36.

8. Sheng Y, He M, Zhao F, Shao C, Miao M. Phylogenetic relationship analyses of complicated class Spirotrichea based on transcriptomes from three diverse microbial eukaryotes: Uroleptopsis citrina, Euplotes vannus and Protocruzia tuzeti. Mol Phylogenet Evol. 2018;129:338-45.

9. Wang Y, Wang C, Jiang Y, Katz LA, Gao F, Yan Y. Further analyses of variation of ribosome DNA copy number and polymorphism in ciliates provide insights relevant to studies of both molecular ecology and phylogeny. Sci China Life Sci. 2019:62:203-14.

10. Yan Y, Fan Y, Luo X, El-Serehy HA, Bourland W, Chen X. New contribution to the species-rich genus Euplotes: morphology, ontogeny and systematic position of two species (Ciliophora; Euplotia). Eur J Protistol. 2018;64:20-39.

11. Zhang T, Qi H, Zhang T, Sheng Y, Warren A, Shao C. Morphology, morphogenesis and molecular phylogeny of a new brackish water subspecies, Neourostylopsis flava paraflava nov. subsp.(Ciliophora, Hypotrichia, Urostylidae), with redefinition of the genus Neourostylopsis. Eur J Protistol. 2018;66:48-62.

12. Zheng W, Wang C, Yan Y, Gao F, Doak TG, Song W. Insights into an extensively fragmented eukaryotic genome: de novo genome sequencing of the multinuclear ciliate Uroleptopsis citrina. Genome Biol Evol. 2018;10: 883-94. 
13. Chen L, Wu W, El-Serehy HA, Hu X, Clamp JC. Morphology, morphogenesis, and phylogeny of an Anteholosticha intermedia (Ciliophora, Urostylida) population from the United States. Eur J Protistol. 2018;65:1-15.

14. Lyu Z, Li J, Qi S, Yu Y, Shao C. Morphology and morphogenesis of a new soil urostylid ciliate, Australothrix xianiensis nov. spec.(Ciliophora, Hypotrichia). Eur J Protistol. 2018;64:72-81.

15. Lyu Z, Li J, Zhu E, Shao C. Morphology and morphogenesis of a new soil urostylid ciliate, with the establishment of a new genus Caudiurostyla gen. nov.(Ciliophora, Hypotrichia). Eur J Protistol. 2018;66:166-76.

16. Berger H. Monograph of the Oxytrichidae (Ciliophora, Hypotrichia). Monographiae Biol. 1999;78:1-1080.

17. Li L, Huang J, Weibo S, Shin MK, Al-Rasheid KA, Berger H. Apogastrostyla rigescens (Kahl, 1932) gen. nov., comb. nov.(Ciliophora, Hypotricha): morphology, notes on cell division, SSU rRNA gene sequence data, and neotypification. Acta Protozool. 2010;49:195-212.

18. Singh J, Kamra K. Molecular phylogeny of an Indian population of Kleinstyla dorsicirrata (Foissner, 1982) Foissner et al., 2002. comb. nov. (Hypotrichia, Oxytrichidae): an oxytrichid with incomplete dorsal kinety fragmentation. J Eukaryot Microbiol. 2014;61:630-6.

19. Song W, Wilbert N. Morphological investigations on some free living ciliates (Protozoa, Ciliophora) from China Sea with description of a new hypotrichous genus, Hemigastrostyla nov. gen. Arch Protistenkd. 1997;148: 413-44.

20. Kaur H, Negi R, Kamra K. Morphological and molecular characterization of Neogastrostyla aqua nov. gen., nov. spec.(Ciliophora, Hypotrichia) from River Yamuna, Delhi; comparison with Gastrostyla-like genera. Eur J Protistol. 2019; 68:68-79.

21. Engelmann TW. Zur Naturgeschichte der Infusionsthiere: W. Engelm.; 1862.

22. Foissner W, Agatha S, Berger H. Soil ciliates (Protozoa, Ciliophora) from Namibia (Southwest Africa), with emphasis on two contrasting environments, the Etosha region and the Namib Desert. Denisia. 2002;5:1-1459.

23. Gong J, Kim SJ, Sy K, Min GS, Roberts DM, Warren A, Choi JK. Taxonomic redescriptions of two ciliates, Protogastrostyla pulchra n. g., n. comb. and Hemigastrostyla enigmatica (Ciliophora: Spirotrichea, Stichotrichia), with phylogenetic analyses based on $18 \mathrm{~S}$ and $28 \mathrm{~S}$ rRNA gene sequences. J Eukaryot Microbiol. 2007;54:468-78.

24. Fan $Y$, Zhao X, Hu X, Miao M, Warren A, Song W. Taxonomy and molecular phylogeny of two novel ciliates, with establishment of a new genus, Pseudogastrostyla n. g. (Ciliophora, Hypotrichia, Oxytrichidae). Eur J Protistol. 2015;51:374-85

25. Berger H. Monograph of the Amphisiellidae and Trachelostylidae (Ciliophora, Hypotricha). Monographiae Biol. 2008:88:1-737.

26. Berger H. Monograph of the Gonostomatidae and Kahliellidae (Ciliophora, Hypotricha). Monographiae Bio. 2011;90:1-741.

27. Shao C, Lu X, Ma H. A general overview of the typical 18 frontal-ventraltransverse cirri Oxytrichidae s.l. genera (Ciliophora, Hypotrichia). J Ocean Univ China. 2015;14:522-32.

28. Song W, Shao C. Ontogenetic Patterns of Hypotrich Ciliates: Science Press Science Press (in Chinese); 2017.

29. Kahl A. Urtiere oder Protozoa. 1. In: Wimpertiere oder Ciliata. 3. Spirotricha In Dahl, F.(ed.), Die Tierwelt Deutschlands und der Angrenzenden Meeresteile, 25. Teil. Jena: Gustav Fisher Verlag; 1932.

30. Wirnsberger E, Foissner W, Adam H. Biometric and morphogenetic comparison of the sibling species Stylonychia mytilus and S. lemnae, including a phylogenetic system for the oxytrichids (Ciliophora, Hypotrichida). Arch Protistenkd. 1986;132:167-85.

31. Foissner W. An update of 'basic light and scanning electron microscopic methods for taxonomic studies of ciliated protozoa'. Int J Syst Evol Microbiol. 2014;64:271-92.

32. Berger H. Monograph of the Urostyloidae (Ciliophora, Hypotricha). Monographiae Biol. 2006;85:1-1304.

33. Foissner W. Ökologie and Taxonomie der Hypotrichida (Protozoa: Ciliophora) einiger österreichischer Böden. Arch Protistenkd. 1982;126:19-143.

34. Foissner W. Faunistic and taxonomic studies on ciliates (Protozoa, Ciliophora) from clean rivers in Bavaria (Germany), with descriptions of new species and ecological notes. Limnologica. 1997;27:179-238.

35. Hemberger H. Neue Gattungen und Arten hypotricher Ciliaten. Arch Protistenkd. 1985:130:397-417.

36. Shao C, Song W, Al-Rasheid KA, Berger H. Redefinition and reassignment of the 18-cirri genera Hemigastrostyla, Oxytricha, Urosomoida, and Actinotricha
(Ciliophora, Hypotricha), and description of one new genus and two new species. Acta Protozool. 2011;50:263-87.

37. Dragesco J, Dragesco-Kernéis A. Ciliés libres de l'Afrique intertropicale: introduction à la connaissance et à l'étude des Ciliés. Faune Tropicale. 1986; 26:1-559.

38. Shao C, Ding Y, Al-Rasheid KA, Al-Farraj SA, Warren A, Song W. Establishment of a new hypotrichous genus, Heterotachysoma n. gen. and notes on the morphogenesis of Hemigastrostyla enigmatica (Ciliophora, Hypotrichia). Eur J Protistol. 2013;49:93-105.

39. Hu X, Song W. Morphology and morphogenesis of a marine ciliate, Gastrostyla pulchra (Perejaslawzewa, 1885) Kahl, 1932 (Ciliophora, Hypotrichida). Eur J Protistol. 2000;36:201-10.

40. Pereyaslawzewa S. Protozoaires de la mer Noire. Zap. Novoross. Obshch. Estestvoisp, vol. 10; 1886. p. 79-114.

41. Wallengren HDJ. Zur Kenntnis der vergleichenden Morphologie der hypotrichen Infusorien, vol. 26. In: Morphologie der hypotrichen Infusorien; 1900.

42. Luo X, Li L, Wang C, Bourland W, Lin X, Hu X. Morphologic and phylogenetic studies of two hypotrichous ciliates, with notes on morphogenesis in Gastrostyla steinii Engelmann, 1862 (Ciliophora, Hypotrichia). Eur J Protistol. 2017;60:119-33.

43. Foissner W. Moon-van der Staay SY, van der Staay GW, Hackstein JH, Krautgartner WD, Berger $\mathrm{H}$. Reconciling classical and molecular phylogenies in the stichotrichines (Ciliophora, Spirotrichea), including new sequences from some rare species. Eur J Protistol. 2004;40:265-81.

44. Wilbert N. Eine verbesserte Technik der Protargo-limpragnation fur Ciliaten. Mikrokosmos. 1975:64:171-9.

45. Lynn DH. The ciliated protozoa: characterization, classification, and guide to the literature. 3rd ed: Springer Science \& Business Media; 2008.

46. Gao F, Warren A, Zhang Q, Gong J, Miao M, Sun P, Xu D, Huang J, Yi Z, Song $\mathrm{W}$. The all-data-based evolutionary hypothesis of ciliated protists with a revised classification of the phylum Ciliophora (Eukaryota, Alveolata). Sci Rep. 2016;6:24874

47. Medlin L, Elwood HJ, Stickel S, Sogin M. The characterization of enzymatically amplified eukaryotic 16S-like rRNA-coding regions. Gene. 1988;71:491-9.

48. Penn O, Privman E, Ashkenazy H, Landan G, Graur D, Pupko T. GUIDANCE: a web server for assessing alignment confidence scores. Nucleic Acids Res. 2010;38:W23-8.

49. Penn O, Privman E, Landan G, Graur D, Pupko T. An alignment confidence score capturing robustness to guide tree uncertainty. Mol Biol Evol. 2010;27: 1759-67.

50. Hall TA. BioEdit: a user-friendly biological sequence alignment editor and analysis program for Windows 95/98/NT. In: Nucleic acids symposium series: 1999. [London]: Information Retrieval Ltd., c1979-c2000.: 95-98.

51. Stamatakis A, Hoover $P$, Rougemont J. A rapid bootstrap algorithm for the RAxML web servers. Syst Biol. 2008:57:758-71.

52. Miller MA, Pfeiffer W, Schwartz T. Creating the CIPRES Science Gateway for inference of large phylogenetic trees. In: 2010 gateway computing environments workshop (GCE); 2010. p. 1-8.

53. Ronquist F, Huelsenbeck J. MrBayes 3: Bayesian phylogenetic inference under mixed models. Bioinformatics. 2003;19:1572-4.

54. Nylander J. MrModeltest 2, vol. 2. Uppsala: Evolutionary Biology Centre, Uppsala University; 2004

55. Page R. Tree View: An application to display phylogenetic trees on personal computers. Bioinformatics. 1996:12:357-8.

56. Tamura K, Dudley J, Nei M, Kumar S. MEGA4: molecular evolutionary genetics analysis (MEGA) software version 4.0. Mol Biol Evol. 2007:24:1596-9.

57. Hillis DM, Bull J. An empirical test of bootstrapping as a method for assessing confidence in phylogenetic analysis. Syst Biol. 1993:42:182-92.

58. Alfaro ME, Zoller S, Lutzoni F. Bayes or bootstrap? A simulation study comparing the performance of Bayesian Markov chain Monte Carlo sampling and bootstrapping in assessing phylogenetic confidence. Mol Biol Evol. 2003;20:255-66.

\section{Publisher's Note}

Springer Nature remains neutral with regard to jurisdictional claims in published maps and institutional affiliations. 